\title{
挿管によるラット気管粘膜傷害とその修復過程における 細胞動態に関する実験的研究
}

\author{
町野満, 服部康夫, 上野 則之
}

\section{Experimental Study on Cytokinetics in Injury Caused by Intubation and the Regeneration Process in Rat Tracheal Mucosa}

\author{
Mitsuru Machino, M.D., Yasuo Hattori, M.D., and Noriyuki Ueno, M.D. \\ Department of Otorhinolaryngology, Nippon Medical School, Tokyo
}

\begin{abstract}
Injury caused by cuff pressure and regeneration in rat tracheal mucosa were examined immunohistochemically using BrdU and electron microscopy. Epithelial defects were observed in almost the whole circumference of the tracheal wall, while the partial existence of the epithelium was recognized in the membranous wall of the trachea. The submucosal layer showed severe edema, bleeding and thrombi. The BrdU labeling indices (L.I.) of the epithelial and submucosal layers started to increase at 12 and 24 hours after treatment, respectively, and reached their peak values in a similar manner at 36 hours. They then drastically decreased until the third and fifth days, respectively, after treatment. The changes in the mitotic indices showed a 12-hour delay compared with those in L.I. Migrating epithelial cells were observed in the area of the regenerating epithelial cells, composed of basal cell-like cells, from 6 to 48 hours after intubation.
\end{abstract}

Key words : tracheal intubation, tracheal mucosa, BrdU, electron microscope, regeneration

\section{I ．はじめに}

気管粘膜傷害の修復過程を形態学ならびに細 胞動態的に観察した研究報告は比較的多数見ら れる。透過電顕的研究は, Hilding ら ${ }^{11}$ の報告が 初めてで，上皮層のみの剥離後の修復について 報告し，4 日後には再生が完了したと述べてい る。細胞動態的には, 永野 ${ }^{2)}$ が ${ }^{3} \mathrm{H}$-thymidine に よるオートラジオグラフィーで上皮の修復を観 察したのが初めてで,気管粘膜上皮の標識率は,

\footnotetext{
日本医科大学耳鼻咽喉科学教室

別刷請求：干206 東京都多摩市永山1-7-1

日本医科大学付属多摩永山病院耳鼻咽喉 科 町野 満
}

投稿受付：1997年 5 月 9 日（急載）
正常群で $1 \%$ ，搔爬後の再生上皮では 3 日後に 正常の15倍となり，6日後になお 2 倍以上であ ったと報告している。

上皮層の再生過程については，山城 ${ }^{3)}$ が搔爬 後の状態を透過電顕的に観察し，既存粘膜上皮 辺緑の細胞群の伸展・移動により再生が始まり, それらの基底細胞が増生，分化したと報告して いる。弓削ら ${ }^{4,5)}$ は山城と同様の研究を行い, 残 存上皮より伸展・移動する細胞群の基底細胞群 よりなる先端部分を移動上皮と名付け，これら が増生，分化して再生したと報告し，服部ら ${ }^{6}$ は，さらに短時間内の細胞動態を観察するため に ${ }^{3} \mathrm{H}$-thymidine によるオートラジオグラフィ 一を行い，移動上皮では，基部の表層から基底 部までが標識されたと報告している。 
固有層の修復について, 鶴窪ら ${ }^{7)}$ は, 搔爬後の 血管新生を鋳型標本で走查電顕的に観察し，血 管数が 2 週間後に 1.2 倍になったと報告し, 梶本 ら ${ }^{8)}$ はカフ圧による傷害と修復を透過電顕と鋳 型標本の走查電顕で観察した結果, 血管新生は 24時間で始まり,血管数は 2 日で2.4倍になった と報告, Hattori ${ }^{9)}$ らは鶴窪ら ${ }^{7)}$, 梶本ら ${ }^{8)}$ と同様 の研究を行い, 血管内皮の再生が上皮に類似し ていたと報告している。

現在までの気管粘膜再生過程に関する研究 は, 観察対象は上皮層がほとんどで，上皮の移 動, 増殖, 分化の経時的推移については明らか となっていない。他方固有層については, 詳細 な観察はわずかで，血管の電顕的観察7 9) があ るにすぎず，線維芽細胞など創傷治癒に関わる 他の細胞には触れられていない。さらに細胞動 態については上皮層のみの観察で，固有層とそ の個々の構成細胞についておよび上皮層との関 連についての研究はほとんど行われていない。

梶本ら ${ }^{8)}$ は，気管粘膜傷害にカフ圧を用いる ことで, 傷害が気管の一定面積で一定深度に限 局され，再生過程の定量的観察に都合が良いこ とを示している。今回, 著者らもこの方法を利 用して, 粘膜傷害モデルを作製し, その再生時 の上皮層と固有層の構成細胞の詳細な細胞動態 を 5-bromo-2'-deoxyuridine (以後 BrdU) を用 いて免疫組織化学的に観察し, あわせて透過電 子顕微鏡的にも観察した。

\section{II . 実験材料および方法}

\section{1. 実験材料}

1 ）実験動物

成熟ウイスター系ラット (雄, 平均体重300 g) 60匹を用いた。恒温恒湿の飼育室でオリエンタ ル固形飼料 MF および水を自由に与え，環境に 適応させるため 4 週間飼育後に実験に供した。

2 ）カフ付気管内チューブ

梶本らの方法 ${ }^{8)}$ に準じて，8Fr.のアトム静脈 カテーテル (侏アトム) に長さ $5 \mathrm{~mm}$ のシリコ ンラバー製カフ（侏 KOKEN）を装着して使用 した。

\section{2. 方法}

1) 挿管

ネンブタール腹腔内麻酔 $(30 \mathrm{mg} / \mathrm{kg})$ を施し，
喉頭直達鏡下に挿管, カフ内に $0.1 \mathrm{ml}$ の蒸留水 を入れ，チューブを引き上げカフの上端が声門 部に当たった所で蒸留水を追加注入して，カフ 圧 $300 \mathrm{mmHg}$ で維持し， 1 時間自発呼吸させ た。蒸留水を抜き抜管した。直後，6，12，24， 36，48時間後，3，5，7，14，21日後に，各 5 匹 ずつをネンブタール過剰腹腔内投与 $(60 \mathrm{mg} /$ $\mathrm{kg}$ ）により屠殺した。上記動物群のうち直後群 を除く各群には，屠殺 1 時間前に BrdU （Sigma） $40 \mathrm{mg} / \mathrm{kg}$ を腹腔内投与した。正常対

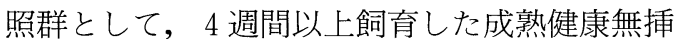
管ラット 5 匹を用いた。

\section{2 ）気管の処理}

ラットを屠殺後，直ちに喉頭を付けたまま気 管を摘出し, 輪状軟骨上で喉頭を切離, 輪状軟 骨より $5 \sim 6 \mathrm{~mm}$ の所で下部気管を切離した, 採取した気管をさらに上下に 2 分して，上半分 を光顕レベルの試料とし，70\%エタノールにて 12時間固定した。系列エ夕ノールにて脱水，石 油ベンゼンにて置換して，パラフィンに包埋し た。水平面あるいは前額面で $4 \mu \mathrm{m}$ の厚さで連 続切片を作製した。

採取した気管の下半分を電顕的観察の試料と した。 $4{ }^{\circ} \mathrm{C}$ の $2.5 \%$ グルタールアルデヒド固定液 （燐酸緩衝液にて pH 7.4に調整）にて 2 時間前 固定， $4{ }^{\circ} \mathrm{C}$ 燐酸緩衝液にて洗浄後，1\%オス ミウム酸固定液（燐酸緩衝液にて pH 7.4に調 整）にて 2 時間後固定した。系列エタノールに て脱水，QY2 にて置換を行い，Quetol 812に包 埋した。超薄切片の作製には Reichert-Nissei Ultra cut N 型超ミクロトームを用い, $80 \mathrm{~nm}$ の 厚さで薄切した。

\section{3. 形態学的ならびに免疫組織化学的観察}

1 ) 光顕的観察

上記連続切片より 2 枚おきに切片を取り出 し，これらを，キシレンにて脱パラフィン，へ マトキシリン・エオジン（H・E）染色を施し， 上皮細胞および粘膜固有層の血管内皮細胞, 線 維芽細胞などの同定と細胞分裂像（後期）の観 察を行った。また, 下記の透過電顕用超薄切片 作製時に得られた厚さ $1 \mu \mathrm{m}$ の切片にメチレン ブルーの単染色を施し，パラフィン切片と同様 の観察を行った。細胞分裂率については，上皮 では全層の細胞を約2000個，固有層では，気管 
一周の固有層の細胞を約 2000 個を数え算定し た。

\section{2 ) 透過電顕的観察}

超薄切片に酢酸ウランと硝酸鉛の 2 重染色を 施し，日立透過型電顕 H7000を用いて，直接倍 率1,000から30,000倍で観察，撮影した。3,000 倍から 30,000 倍に焼付けた写真を，上皮層と粘 膜下固有層の構成細胞の同定および上皮細胞の 分化程度の判定に用いた。

3 ) 免疫組織化学的観察

上記連続切片の残りには以下に述べる方法 で, 免疫組織化学的処理を行った。キシレンに て脱パラフィン, エタノールで加水処理，0.3\% $\mathrm{H}_{2} \mathrm{O}_{2}$ 加メタノールで内因性ペルオキシダーゼ をブロックした後， $2 \mathrm{~N}-\mathrm{HCl}$ で塩酸処理した。 さらに正常ウサギ血清で非特異的反応をブロッ クし，DAKO LSAB キット（DAKO）を用いた labeled streptavidin biotin（LSAB）法で以下 の抗体による染色を行った。1次抗体として抗 BrdU マウス・モノクローナル抗体 (DAKO 製) を overnight で反応させた。PBS で洗浄後，2 次抗体としてビオチン標識抗マウス IgGウサ ギポリクローナル抗体（DAKO 製）と40分間反 応させ,さらにPBS で洗浄後, ペルオキシダー ゼ標識ストレプトアビジンで10分間反応後, PBS で洗浄し， $5 \% \mathrm{H}_{2} \mathrm{O}_{2}$ 加3.3'-diaminobenzidine $4 \mathrm{HCl}$ (DAB) で発色させ，PBS で反応 停止後メチルグリーンで核染色を行った。

ヘマトキシリン・エオジン染色標本と対比し つつ，気管全周の上皮層全層の細胞約 2000 個， 固有層の全層の細胞約 2000 個と腺組織，血管内 皮細胞，線維芽細胞をそれぞれ約1000個を観察 し, 各組織, 細胞ごとの BrdU 標識細胞の比率 ％，labeling index）を算定した。

4 ) 統計学的検討については, Wilcoxon 順 位和検定を用いた。

\section{III. 結 果}

\section{1. 形態学的観察}

\section{1) 正常対照群}

気管粘膜は，上皮層，基底膜，固有層よりな り，気管軟骨へと移行し，膜様部では筋層へと 移行していた。上皮層は多列線毛上皮で，電顕 的には, 線毛細胞, 分泌細胞, 刷子細胞および
基底細胞であった。これら上皮細胞の平均出現 頻度は線毛細胞 $33.8 \%$ ，杯細胞 $43.7 \%$ ，基底細 胞 $22.5 \%$ であり，刷子細胞はごくわずかに見ら れ，粘膜固有層では基底膜と弾力縦束の間に少 数の血管と線維芽細胞が見られた。弾力縦束に 囲まれて, 血管, 線維芽細胞, リンパ球, とき に肥満細胞も見られた。弾力縦束の直下には, 長紡鍾形の線維芽細胞が $1 \sim 2$ 層に重層して軟 骨膜へと移行していた。気管腺は軟骨と軟骨の 間あるいは膜様部の固有層中層から深層に散在 していた。細胞成分と弾力縦束以外の部分は, 膠原線維束と無構造物質で埋められていた（図 1 )。

\section{2 ）挿管群}

傷害部位は, 縦断では声門より $0.6 \mathrm{~cm}$ 下方の 範囲に，水平断では，軟骨部ほぼ全体にわたっ て上皮層が欠損して, 全周の約 6 分の 5 を占め ていた。膠原線維束が露出あるいは部分的に痂 皮形成が見られた。膜様部および軟骨と軟骨の 間には，部分的に基底細胞のみの残る部分，対 照群上皮層と変化のない健常部分とその中間の 部分が観察された。固有層では, 気管壁全周に

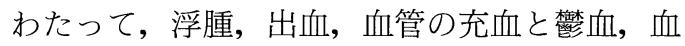
栓形成などが見られ, 細胞成分の多くは浮腫状 あるいは壊死に陥り, 染色性が低下していた。 しかし，血管壁の傷害は比較的軽度で，染色性 の低下も少なかった。弾力縦束は保存され, 腺 組織の傷害も軽かった。固有層の厚さは対照群 の数倍になっていた（図 2 )。

挿管後 6 時間では，健常部分の辺縁には，1 から $3 \sim 4$ 層に配列し, 小型で核細胞質比の大 きい細胞群よりなる移動上皮 (弓削ら ${ }^{4}$, 服部 $ら^{6)}$ の移動上皮と同質の再生上皮で，細胞内小 器官の分布状況が健常群基底細胞と類似の細胞 群よりなる。図 3 ) が見られた。固有層では, 炎症反応が増強していた。

12 時間後には，気管壁の 3 分の 1 程度が，上 皮層に被覆され，移動上皮は，その 2 分の 1 を 占めていた。固有層では血栓は認められなくな った。

24 時間後には，気管壁の 2 分の 1 程度が上皮 層に被覆され，移動上皮部分は健常部分（傷害 時に保存された残存上皮層と分化成熟した再生 上皮細胞群）とほぼ同程度で，両者の間の表層 
細胞に，線毛の前駆体を持つ細胞と分泌顆粒を 少数持つ細胞とが介在していた（以後，移行部 分)。細胞分裂像が健常部分では基底部に, 移行 部分と移動上皮基部では基底部から表層細胞に 観察された。固有層では, 血管と線維芽細胞に 細胞分裂像が観察された。

36時間後には，気管壁の 3 分の 2 以上が上皮 層に被覆され, 健常部分が 2 分の 1 , 移行部分 が 4 分の 1 , 移動上皮が 4 分の 1 を占めていた。 細胞分裂像は図 4 のように上皮層で多数観察さ れた。固有層では, 浮腫は軽減傾向にあったが, 血管と線維芽細胞がさらに増加して, 肉芽形成 が著明となっていた（図 5 )。

48時間後には，気管壁のほぼ全体が上皮層に 被覆され, 移動上皮が 4 分の 1 弱, 健常部分が 2 分の 1 強, 移行部分が 4 分の 1 強であった。

3 日後では, 移動上皮は見られず, 健常部分 が 3 分の 2 , 移行部分が 3 分の 1 となった。移 動上皮様に見える部分でも電顕的には図 6,7 , 8 のように分化が進んでいるのが確認された。 固有層では, 浮腫と好中球が減少, 血管と線維 芽細胞は24時間群と変化がなく, 膠原線維の増 生が明らかであった。
5 日後では上皮層のほとんどが健常部分で, 所々に移行部分があった。7日後以後, 上皮層 はすべて健常部分よりなり，個々の細胞の分化 程度は正常対照群と差異はなかった。固有層で は好中球は見られず，血管系はなお豊富で, 線 維芽細胞は減少したものの胞体の肥大が見られ た。

\section{2. 細胞分裂率}

対照群では細胞分裂率 (mitotic index： M.I.) は上皮層で平均 $0.11 \%$ で, 固有層では 0.01 \%以下であった。この時間的推移を表 1 に示し た。

6 時間後, 細胞分裂像が傷害後初めて健常部 基底部に観察されたが，上皮層全体，固有層全 体でも対照群と有意差がなかった $(p \geqq 0.1) 。 24$ 時間後には，上皮層全体で平均 $1.84 \%$ と対照群 より有意に多く $(p<0.05)$, 固有層全体でも平 均 $0.48 \%$ と対照群より増加傾向にあった。36時 間後には，上皮層全体で平均 $2.03 \%$ (上皮層の 最高値）となり，48時間後でも，平均 $2.00 \%$ と 前群とほほ同值であった。一方，固有層では， 48時間で平均 $1.06 \%$ と最高值を示した。 3 日後 以降 M.I. は上皮層全体, 固有層全体ともに減少

\section{〔図説明]}

(1)対照群の気管粘膜全層を示す。上皮層は多列線毛上皮からなり, 線毛細胞 (CC), 分泌細胞 (SC) およ び基底細胞 (BC) により構成されている。粘膜固有層との間には基底膜が明膫である。粘膜固有層には膠原 線維 $(\mathrm{CF})$ と弾力線維 $(\mathrm{EF})$ が豊富で, 細胞成分として細静脈 $(\mathrm{Ve})$, 線維芽細胞 (FB) などが見られる。 粘膜固有層は軟骨膜 $(\mathrm{PC})$, 気管軟骨 $(\mathrm{TC})$ へと移行している。 $\times 3,000$

(2)挿管直後群の粘膜全層を示す。上皮層は脱落。固有層は浮腫が著明で，厚さが対照群の数倍となり，フ ィブリン（F）の析出と壊死細胞（矢印）が多数見られる。細静脈では血管壁が血小板（星印）で置き換わっ ているものがある。 $\times 2,000$

(3)抻管後 6 時間群の移動上皮 (ME) を示す。一層に配列し, 細胞内小器官の分布は基底細胞と類似してい る。 $\times 7,500$

(4)择管後36時間群の再生上皮 (RE) 内の細胞分裂像 (Mi) を示す。その周囲の各細胞は類似し，細胞間橋 が発達し，表層細胞には分泌顆粒が見られる。 $\times 6,000$

(5)挿管後36時間群の粘膜全層を示す。再生上皮 $(\mathrm{RE})$ は $2 \sim 3$ 層に配列し，表層細胞には分泌顆粒が見ら れる。粘膜固有層では浮腫が軽減し, 細胞成分が増加している。線維芽細胞の肥大と細胞分裂像 $(\mathrm{Mi})$, 大食 細胞 $(\mathrm{Ph}) ，$ リンパ球 $(\mathrm{Ly})$ などが見られる。 $\times 2,500$

6)挿管後 3 日群の再生上皮（RE）を示す。細胞配列は移動上皮に類似するが，細胞間橋形成は不明瞭で， 表層の細胞では胞体が大きくなっている。 $\times 4,500$

(7)挿管後 3 日群の再生上皮表層細胞を示す。自由表面細胞膜下に, centriole (Ce), procentriole precursor body (PPB), procentriole organizer (PCO), procentriole (PC) などの線毛の前駆体が見られる ${ }^{19,20) 。 ~}$ $\times 30,000$

(8)挿管後 3 日群の再生上皮表層細胞を示す。自由表面細胞膜下あるいは細胞膜に接して, 分泌顆粒(矢印) が見られる。 $\times 30,000$

(9)対照群の気管粘膜での BrdU 標識細胞を示す。標識細胞は上皮層基底細胞に散見される。

(10)挿管後36時間の再生気管粘膜の BrdU 標識細胞を示す。標識細胞は著明に増加し，移動上皮の表層細胞 と，固有層の線維芽細胞と血管内皮に標識細胞が見られる。 
日気食会報，48（4），1997

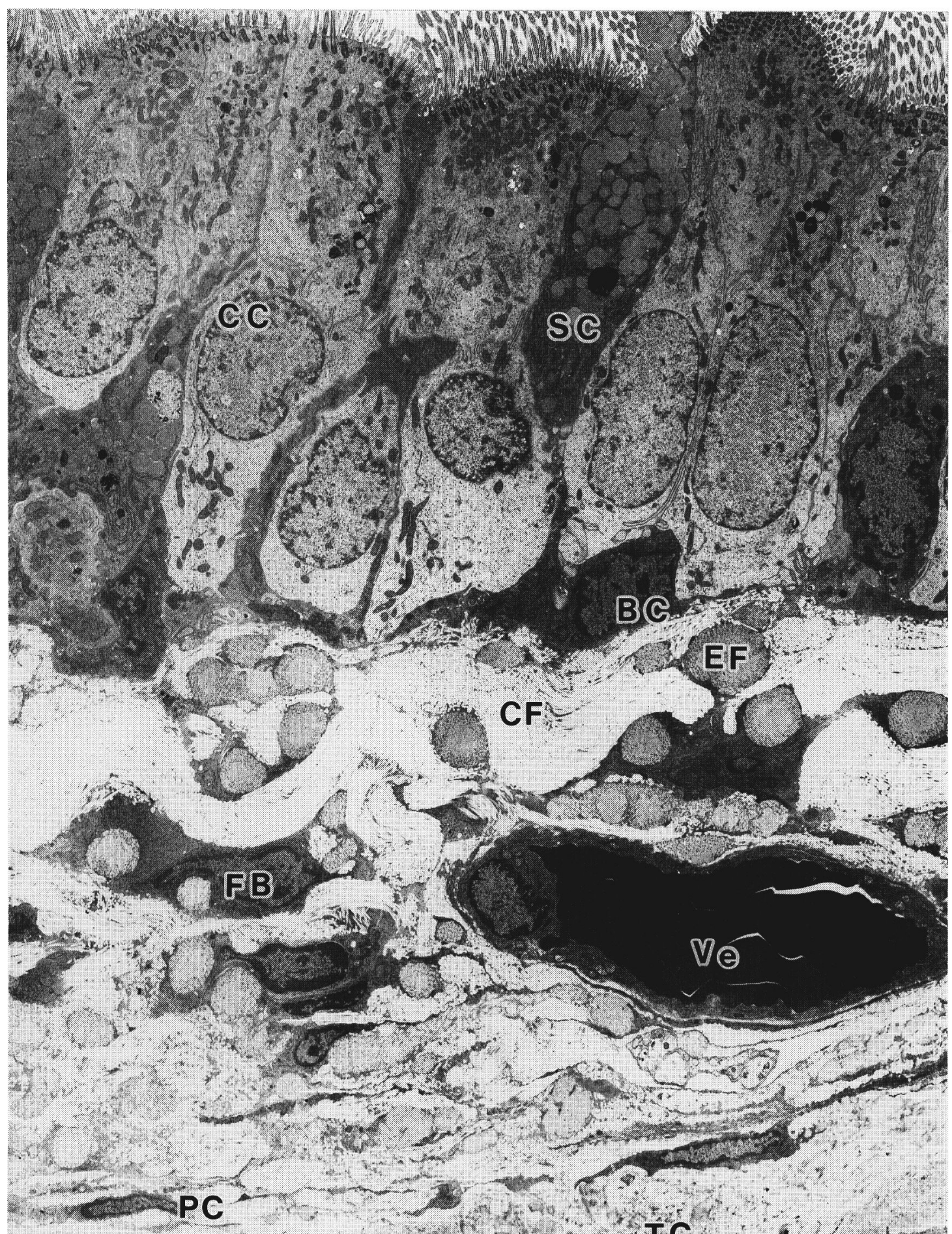

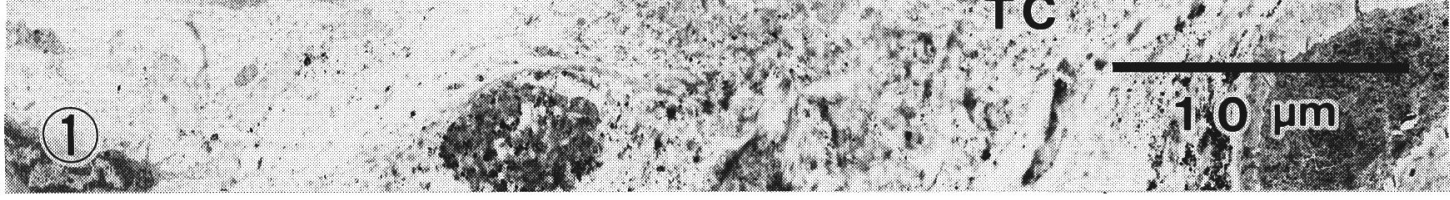

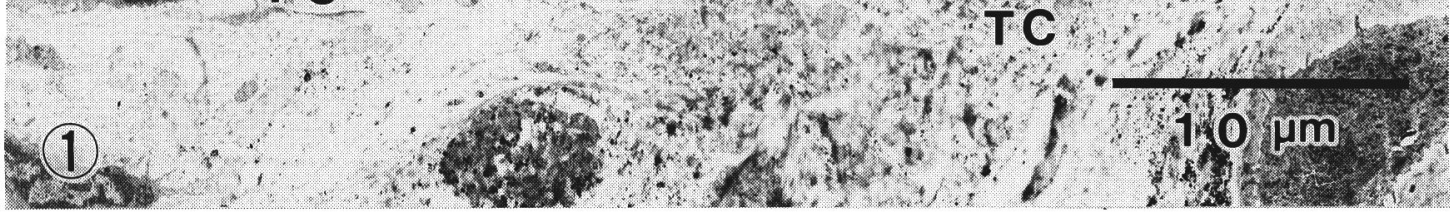


日気食会報，48（4），1997

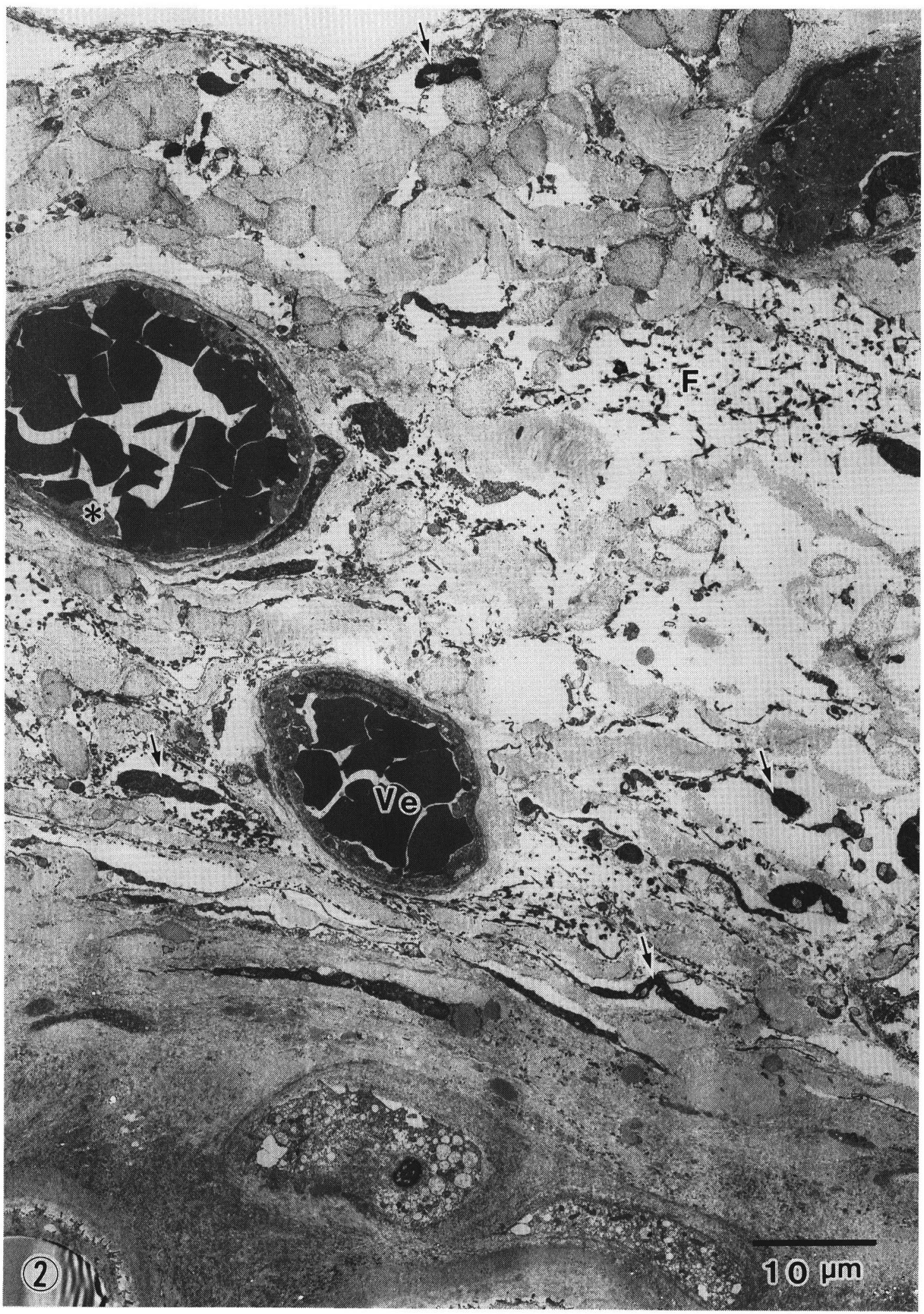


日気食会報，48（4），1997
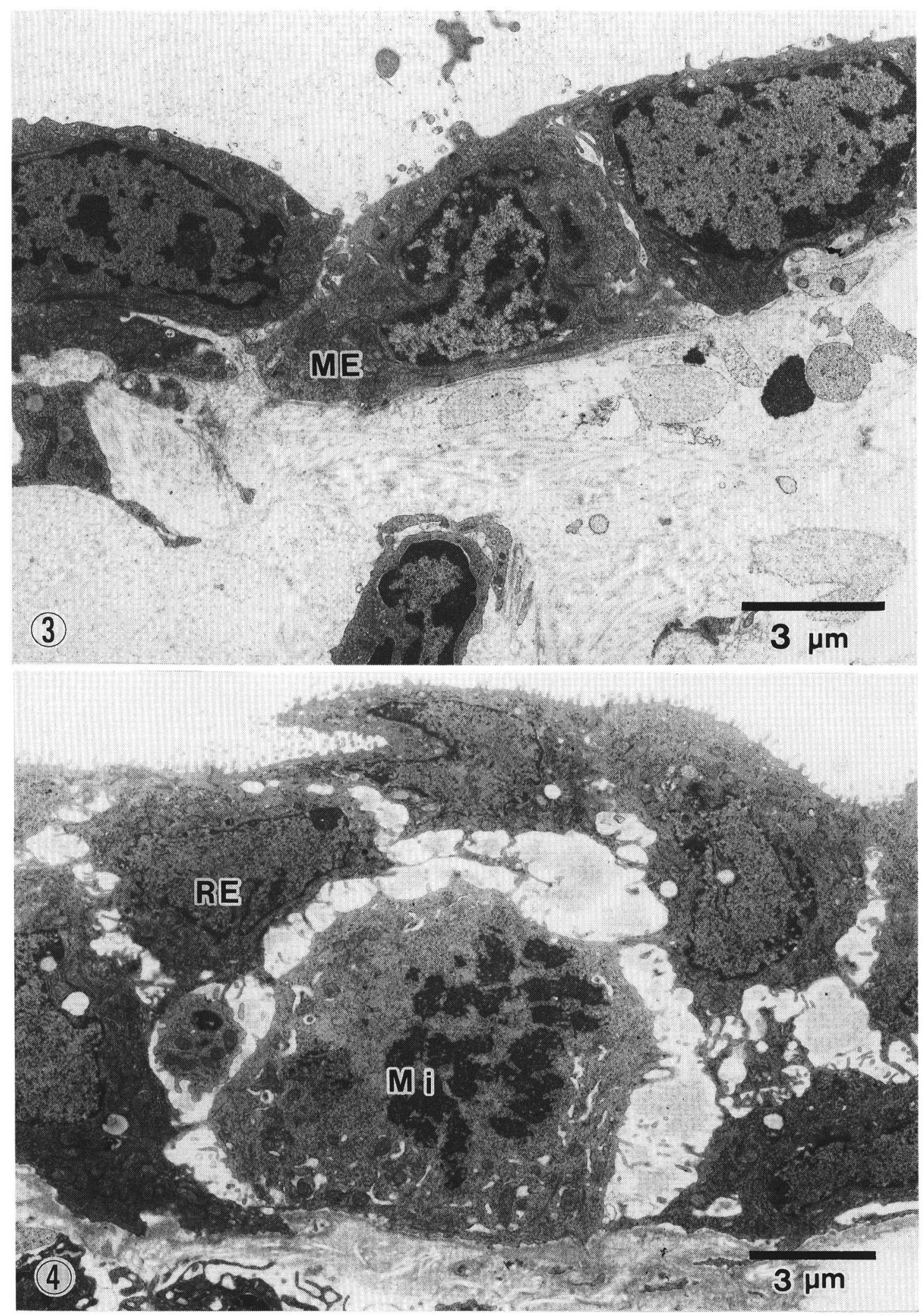
日気食会報，48（4），1997

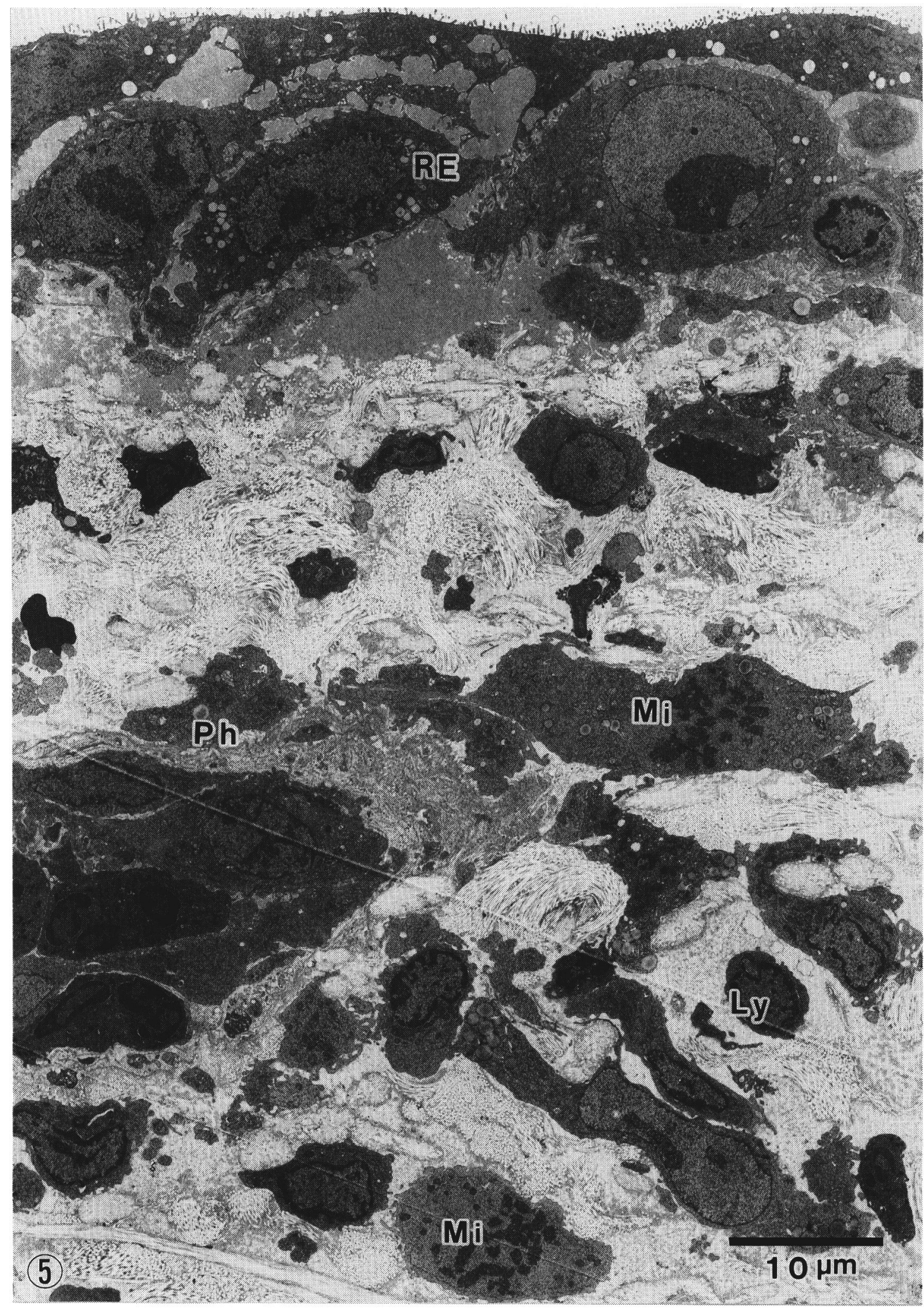







日気食会報，48（4），1997

(1).

.

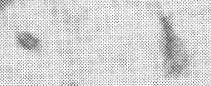

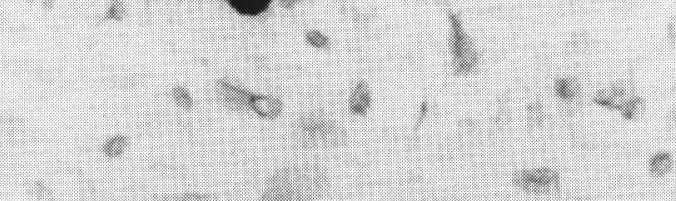

(9)
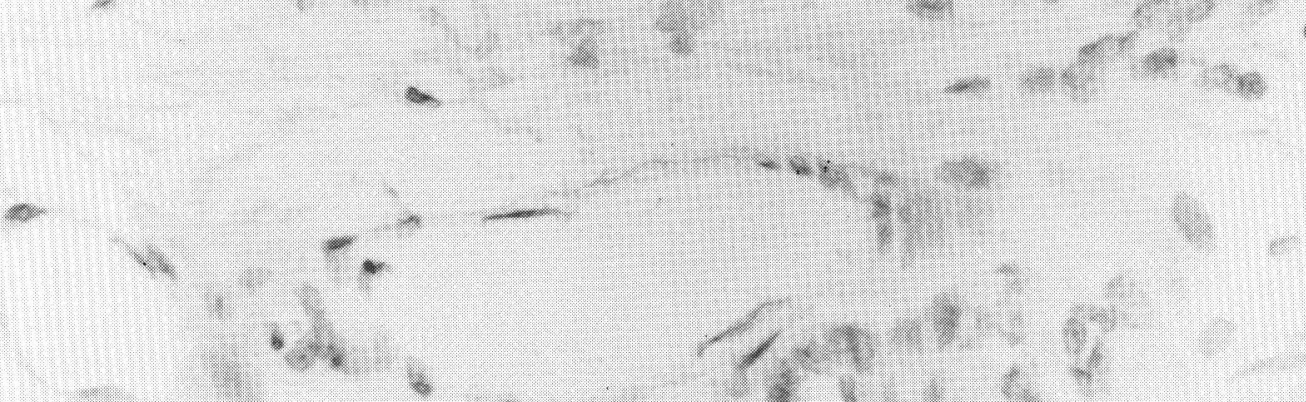

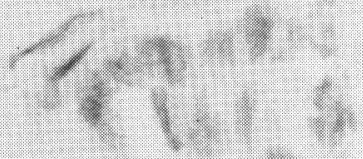

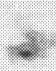

.0.

(2.

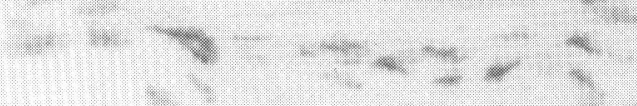

L

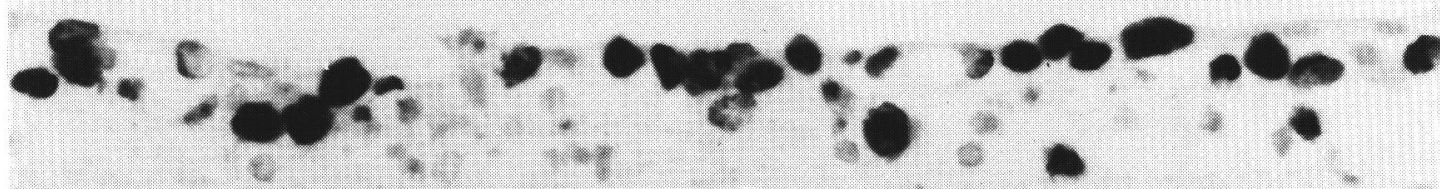

*

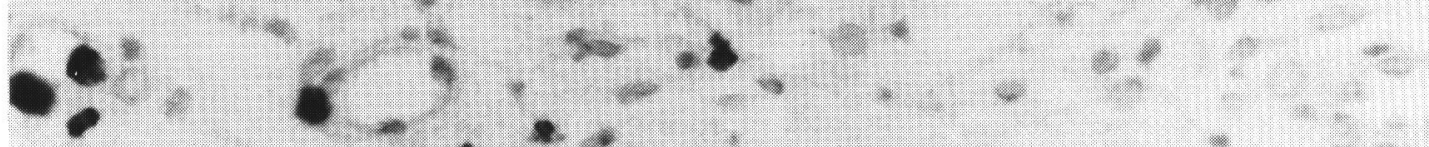

(10)

(3): 
表 1 粘膜上皮層・固有層の細胞分裂率（M.I.）と BrdU 標識率（L.I.）

\begin{tabular}{|c|c|c|c|c|c|c|c|c|}
\hline & \multicolumn{2}{|c|}{ M.I. (\% $\%$ S.D. $)$} & \multicolumn{6}{|c|}{ L.I. (\% $\%$ S.D. $)$} \\
\hline & 上皮層 & 固有層 & 上皮層全体 & 移動上皮 & 固有層全体 & 線維芽細胞 & 血管内皮細胞 & 腺 組 識 \\
\hline 対照群 & $0.11 \pm 0.11$ & $0 \quad \pm 0$ & $1.42 \pm 0.53$ & - & $2.12 \pm 0.90$ & $2.22 \pm 1.06$ & $2.00 \pm 1.06$ & $1.72 \pm 1.18$ \\
\hline 0 時間群 & $0 \quad \pm 0$ & $0 \quad \pm 0$ & $0.41 \pm 0.69^{*}$ & $0.52 \pm 1.16$ & $0.57 \pm 0.33^{* *}$ & $0.66 \pm 0.62$ & $1.32 \pm 1.43$ & $1.37 \pm 2.08$ \\
\hline 6 時間群 & $0.13 \pm 0.19$ & $0 \quad \pm 0$ & $0.72 \pm 0.70$ & $6.20 \pm 0.44$ & $1.04 \pm 0.86$ & $2.68 \pm 2.15$ & $1.46 \pm 1.74$ & $2.68 \pm 2.16$ \\
\hline 12時間群 & $0.62 \pm 0.74$ & $0.16 \pm 0.21$ & $15.9 \pm 10.6^{* *}$ & $15.8 \pm 10.1^{* *}$ & $2.40 \pm 2.23^{*}$ & $3.18 \pm 3.00$ & $1.74 \pm 1.87$ & $4.82 \pm 3.08$ \\
\hline 24時間群 & $1.84 \pm 0.57^{*}$ & $0.48 \pm 0.75$ & $36.3 \pm 9.3 \dagger$ & $41.5 \pm 20.6^{* *}$ & $10.5 \pm 3.9^{* *}$ & $20.6 \pm 10.9^{* *}$ & $12.7 \pm 5.7^{* *}$ & $3.84 \pm 4.53$ \\
\hline 36 時間群 & $2.03 \pm 1.06^{*}$ & $0.98 \pm 0.83$ & $43.0 \pm 10.3 \dagger$ & $52.0 \pm 8.7$ & $16.1 \pm 2.7 \dagger$ & $27.0 \pm 2.2$ & $15.0 \pm 3.4$ & $16.9 \pm 17.2$ \\
\hline 48時間群 & $2.00 \pm 0.72 * *$ & $1.06 \pm 0.68^{* *}$ & $26.7 \pm 9.4^{*}$ & $40.5 \pm 16.6^{* *}$ & $14.1 \pm 5.4 \dagger$ & $21.9 \pm 14.0$ & $14.4 \pm 11.7$ & $13.3 \pm 7.5$ \\
\hline 3 日群 & $1.18 \pm 1.04^{*}$ & $0.89 \pm 0.47^{* *}$ & $4.02 \pm 3.14^{* *}$ & - & $8.58 \pm 2.79 \dagger$ & $10.9 \pm 2.8$ & $6.40 \pm 2.25 \dagger$ & $6.10 \pm 6.89$ \\
\hline 5 日群 & $0.36 \pm 0.20$ & $0.50 \pm 0.31 * *$ & $2.70 \pm 1.06$ & - & $2.38 \pm 0.40 \dagger$ & $2.73 \pm 0.94^{* *}$ & $2.20 \pm 0.55^{* *}$ & $2.32 \pm 1.64$ \\
\hline 7 日群 & $0.39 \pm 0.13$ & $0.25 \pm 0.35^{*}$ & $1.63 \pm 0.76$ & - & $2.38 \pm 0.77$ & $3.12 \pm 1.00$ & $2.42 \pm 1.33$ & $0.46 \pm 0.35^{*}$ \\
\hline 14 日群 & $0.05 \pm 0.03$ & $0.05 \pm 0.09$ & $0.89 \pm 0.28$ & - & $2.36 \pm 0.88$ & $3.66 \pm 1.55$ & $1.44 \pm 1.24$ & $0.56 \pm 0.64$ \\
\hline 21 日群 & $0.02 \pm 0.04$ & $0 \quad \pm 0$ & $0.63 \pm 0.16$ & - & $1.57 \pm 0.45$ & $2.28 \pm 0.88$ & $1.81 \pm 1.77$ & $0.81 \pm 0.58$ \\
\hline
\end{tabular}

*：M.I.については対照群に対する有意差（ $p<0.05 ）$ 。L.I. については前群に対する有意差 $(p<0.05)$ 。

**：M.I. については対照群に対する有意差（ $p<0.01 ）$ 。 L.I.については前群に対する有意差 $(p<0.01)$ 。

$†$ : 前群に対し危険率10\%以下 $(p<0.1)$ 。

を示し，7 日後上皮層では前群と有意差はなく なった。固有層では，7日後でも対照群より多 く $(p<0.05), 14$ 日後で対照と有意差はなくな った。

\section{BrdU による免疫組織化学的観察}

対照群の BrdU 標識細胞は, 上皮層では基底 部の細胞にのみ見られ (図 9), labeling index

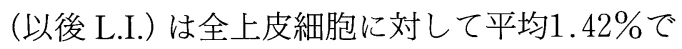
あった。固有層では, 全体でL.I. が平均 $2.12 \%$, 線維芽細胞で平均 $2.22 \%$, 血管内皮細胞で平均 $2.00 \%$ ，腺組織で平均 $1.72 \%$ であった。の BrdU 標識細胞の時間的推移を表 1 に示した。

挿管直後では L.I. は上皮層全体および固有 層全体で表 1 のように対照群より有意に低値を 示し $(p<0.05, p<0.01), 12$ 時間後より全上皮 層で有意に増加し，36時間後には $43.0 \%$ と最高 値に達した(図10)。48時間後より減少し，3日 後まで前群に対し有意に減少し，5日後には $2.70 \%$ となり，5 日以降前群に対し有意差はな くなり徐々に減少していった。移動上皮では, 上皮層全体とほぼ同様に推移し, 最高値は5 2.0 \%であった。一方, 固有層全体でも12時間後よ り有意に増加し，36時間後には $16.1 \%$ と最高值
に達した(図10)。48時間以降は減少に転じ， 5 日まで前群に対し有意に減少した。7日以降21 日まで前群に対し有意差はなくなった。固有層 の各細胞も36時間で最高値に達し, 血管内皮細 胞で $15.0 \%$, 線維芽細胞で $27.0 \%$, 腺組織で 16.9 \%であった。それ以降，血管内皮細胞と線維芽 細胞は 5 日まで, 腺組織では 7 日まで前群に対 し有意に減少し, それぞれこの後は有意差はな くなった。

\section{IV. 考 察}

\section{1 . 気管粘膜上皮層, 固有層全体の修復につ いて}

気道上皮組織の再生の形態学的研究は多い が1 6,10 16), その固有層の再生に触れた報告は少 ない ${ }^{7 \sim 9)}$ 。気管上皮の再生について, Shimizu $ら^{10)}$, Liu $ら^{11)}$ は, 残存上皮の migration とその dedifferentiation, proliferation と redifferentiation の 3 時期を経て再生するとしている。本 実験でも，上皮層では，残存上皮層からの migration が観察され, これが増殖, 分化して再 生が完了し, migration に関わった細胞群は, 細 胞内小器官の分布状況が基底細胞のそれに類似 
していた。弓削ら ${ }^{5)}$ は, 形態的に基底細胞そのも のであるとし，移動上皮と名付けている。近年 の見解では，再生上皮の増殖細胞について， Inayama ら ${ }^{12)}$ は基底細胞が起源であると, Shimizu ${ }^{10)}$ と Liu $ら^{11)}$ は分泌細胞と基底細 胞が起源であると推定している。移動上皮の構 成細胞の起源はまだ確定されてはいないが，移 動上皮は初期の再生上皮にのみ見られ，L.I. か らみても高い増殖能を持っているといえる。そ の同定は電顕的観察だけでは困難で, PAS 染色 などの特殊染色と免疫組織化学的観察が必要で あり，今後の研究が待たれる。

一方，固有層では，形態的には炎症性修復の 過程をたどったが，上皮層の修復完了時にも炎 症反応は消退していなかった。細胞動態的にみ ても，M.I. は，上皮層では，36時間後に最高値 を示し，5日後以降には元に復した。固有層で は，48時間後に最高値を示し，14日後以降には 元に復した。さらに L.I. の推移も M.I. と同様な 曲線を描いたが，M.I. より約12時間早く推移し た。上皮層の修復が，固有層のそれよりも早か ったことは，Block ら ${ }^{13)}$ が舌粘膜切開後の修復 をオートラジオグラフィ的に観察して，上皮の 修復が先行すると報告したのとよく一致してい る。これは，上皮層では細胞成分のみよりなり， 修復すべき構成成分が単純であり，壊死細胞は 容易に管腔へ脱落すること，さらに再生上皮が 高い増殖能を持ち，かつ増殖能をもつ細胞の絶 対数が多いために修復はスムースに進行すると 考えられる。他方，固有層では，細胞成分のほ かに，間質成分が加わり，修復すべき構造が上 皮層より複雑であり，さらに壊死細胞の排除に 實食細胞が関与する。そのため，上皮層より修 復が遅れたと考えられる。

M.I. と L.I. の関係について，一般に動物の分 裂組織内では，細胞周期は約 24 時間で，S 期は 約 8 時間， $\mathrm{M}$ 期は 2 時間程度で，細胞分裂像を 観察しやすいのは，M期のうち中期と後期で約 20分間に限られるとされている ${ }^{17)}$ 。本実験では, M.I. の最高值は L.I. の約 20 分の 1 程度の值で あった。M.I. の算定に，M期のうちでも後期の 細胞を対象としたためにこのような結果となっ たと考えられる。

\section{2．固有層細胞成分の増殖力について}

一般に肉芽形成に際して, 線維芽細胞は血管 新生とほぼ同時に増殖するが，線維芽細胞のみ が単独に増殖することがあるとも言われてい る ${ }^{18)}$ 。また一方で, Keenan ら ${ }^{14)}$ は八ムスターの 気管の実験で，血管内皮は線維芽細胞より ${ }^{3} \mathrm{H}^{-}$ thymidine の取り込みが早期に始まったと報告 している。本実験では，線維芽細胞と血管内皮 の L.I. の推移は一致し，線維芽細胞の L.I. は血 管内皮細胞に比べ高い值を示し，線維芽細胞の 増殖力のほうがより高まっていた。この両者の 増殖力の差は，血管系では，傷害が比較的軽度 で, 梶本ら ${ }^{8)}$ が述べているように，その修復は極 めて早く進み，早期に再血行したと考えられ， また肉芽形成も比較的軽度であったために，必 要細胞数が多くなかったと考えられる。これに 対し，線維芽細胞では，壊死に陥ったものが多 いことと，細胞外成分の崩壊が著しく，その再 構成に関わる細胞も必要となり，結果的に線維 芽細胞の増殖力がより旺盛となったと考える。

\section{V.まとめ}

ウイスター系雄性ラットの気管壁に, 過大な カフ圧を加え，その傷害と修復の過程を形態学 的ならびに BrdUを用いて免疫組織化学的に 観察した。

1）気管粘膜の傷害は，上皮層では上皮の脱 落，固有層では高度の浮腫，細胞成分の変性・ 壊死として見られた。しかし，膜様部と気管軟 骨輪間では傷害が見られないことがあった。

2 ) $\mathrm{BrdU}$ 標識率の平均は，対照群では上皮 層で $1.4 \%$ ，固有層で $2.1 \%$ に対し，挿管群では 上皮層，固有層ともに12時間で増加が始まり， それぞれ $16.5 \% ， 3.3 \%$ と 36 時間で最高値とな り，上皮層で $43.0 \%$ ，固有層で $16.1 \%$ であった。 上皮層では 3 日まで急減し，固有層では 5 日ま で急減した。

3）細胞分裂率の平均は，対照群では上皮層 で $0.11 \%$ ，固有層では $0.01 \%$ 以下であった。挿 管群では上皮層，固有層ともに12時間で増加が 始まり，上皮層では 36 時間で $2.0 \%$ と最高值，固 有層では 48 時間で $1.1 \%$ と最高値を示した。上皮 層では 5 日，固有層では14日で対照群と類似の 值となった。 
4 ）再生上皮の一部で, 細胞内小器官の分布 が基底細胞のそれに類似する細胞群のみよりな る移動上皮は，扦管 6 時間より48時間までの間 に観察された。

稿を終えるにあたり，御校閲を賜った八木聰明教 授ならびに本学病理学第二教室浅野伍朗教授に深く 感謝致します。さらに御協力を頂きました本学第一 病院電子顕微鏡室並松茂樹係長に感謝の意を表しま す。

本論文の要旨は第47回日本気管食道科学会総会 （1995年，名古屋）において報告した。

\section{文献}

1) Hilding, D.A., and Hilding, A.C. : Ultrastructure of tracheal cilia and cells during regeneration. Ann. Oto. Rhino. Laryngol., $75: 281-294,1966$.

2 ) 永野泰宏: 気管粘膜上皮の再生に関するオート ラジオグラフィーによる研究。日医大誌， 36 ： 1-11, 1989.

3 ）山城義昭：搔爬気管粘膜の再生に関する病理組 織学的研究補遗. 日耳鼻, $77: 981-1007,1974$.

4 ）弓削庫太, 服部康夫, 村上享司 - 他：搔爬気管 粘膜の修復に関する電子顕微鏡的観察.耳展, 18(補 3 )：255-267, 1975.

5 ）弓削庫太, 服部康夫, 村上享司 - 他: 搔爬気管 粘膜の修復に関する電顕, 並びにオートラジオ グラフィーによる観察.耳展, 21(補 2 )：109125, 1978.

6 ）服部康夫, 中村兼一, 村上忠也 - 他：気管粘膜 の再生・修復に関する電顕的観察一粘膜搔把の 繰り返しによる修飾，および再生上皮と胎生期 粘膜上皮の分化との比較一. 日耳鼻, $85 ： 891-$ 902, 1982

7 ）鶴窪一行, 服部康夫：ラット搔爬気管粘膜の血 管系の再生に関する電顕的観察. 日耳鼻，93： 1207-1221, 1990

8 ）梶本正子, 服部康夫：挿管の気管粘膜におよぼ す影響に関する形態学的観察一血管傷害とその 再生一。耳鼻，37(補 4)：1028-1045, 1991.

9 ) Hattori, Y., Tsurukubo, K., Nakamura, K., et al. : Electron microscopic study of vascular regeneration in rat tracheal mucosa follow- ing physical curettage. Auris $\bullet$ Nasus $\bullet$ Larynx. (Tokyo), 19:251-269, 1992.

10) Shimizu, T., Nisihara, M., Kawaguchi, S., et al. : Expression of phenotypic markers during regeneration of rat tracheal epithelium following mechanical injury. Am. J. Respir. Cell Mol. Biol., 11 : 85-94, 1994.

11) Liu, J.Y., Nettesheim, P., and Randell, S.H. : Growth and differentiation of tracheal epithelial progenitor cell. Am. J. Physiol., 226 : 296-307, 1994.

12) Inayama, Y., Hook, G.E., Bray, A.R., et al. : In vitro and in vivo growth and differentiation of tracheal basal cells. Am. J. Pathol., 134：539-549, 1989.

13) Block, P., Steiter, I., and Oehlert, W. : Autoradiographic studies of the initial cellular response to injury. Exp. Cell Res., 30 : 311321, 1963.

14) Keenan, K.P., Combs, J.W., and McDowell, E. M. : Regeneration of hamster tracheal epithelium after mechanical injury. Virchows Arch. (Cell Pathol.), 41 : 193-214, 1982.

15) Keenan, K.P., Wilson, T.S., and McDowell, E. M. : Regeneration of hamster tracheal epithelium after mechanical injury. Virchows Arch. (Cell Pathol.), 43：213-240, 1983.

16) McDowell, E.M., Combs, J.W., and Newkirk, C. : Changes in secretory cell of hamster tracheal epithelium in response to acute sublethal injury-A quantitative study - . Exp. Lung Res., 4 : 227-243, 1983.

17）堀田康男：細胞分裂と細胞周期. 細胞の構造と 機能 II（太田行人，岡田節人，岡田善雄編）, pp.117-216，岩波書店，東京， 1975 .

18）白澤春之：炎症．現代の病理学（横山 武，福 西 亮，綿貫 勤，喜縮 勇編)，pp.186-276， 金原出版, 東京, 1984 .

19) Sorkin, S.P. : Reconstruction of centriole formation and coliogenesis in mammalian lung. J. Cell Sci., 3 : 207-230, 1968.

20) Steinman, R.M. : An electron microscopic study of ciliogenesis in developing epidermis and trachea in the embryo of xenopus laevis. Am. J. Anat., 122 : 19-56, 1968. 